\title{
USING ATP TESTS FOR ASSESSMENT OF HYGIENE RISKS
}

\author{
WYKORZYSTANIE TESTÓW ATP \\ DO OCENY ZAGROŻEŃ ZWIĄZANYCH Z HIGIENĄ
}

\begin{abstract}
Adenosine-5'-triphosphate (ATP) is a high-energy molecule playing a role of universal energy carrier used in cell metabolism. Since ATP is present in both prokaryotic and eukaryotic cells, this coenzyme can be used to determine a hygiene state. During last decade there has been a significant growth of practical applications of ATP measurements. ATP tests are commonly used for an assessment of hygienic conditions in food industry, residential buildings and hotels. In comparison with traditional and time-consuming laborious microbial analysis the measurement of ATP provides a quick indicative on-site data, characterizing microbial and organic contamination to support decision-making with regards to adequate corrective and preventive actions. This paper demonstrates applications of ATP in practice and, particularly, in water treatment technology and wastewater processing. The review highlights opportunities for using the test for the optimization of water treatment facilities and pipe networks functioning in order to assess wastewater toxicity and wastewater treatment process efficiency. Other areas of application are also addressed. The review of literature indicates that ATP used in different areas of industry can be considered as a diagnostic method - complement the classical methods - useful for identification of hygiene risks as well as a tool for a real-time management of health and environmental risks.
\end{abstract}

Keywords: adenosine-5'-triphosphate (ATP), bioluminescence, identification of hygiene risks, risk management

\section{Introduction}

The classic methods for microbial monitoring of water, food products, hygiene state of food production plants, hospitals, shops or hotels do not provide a real time assessment of risks. Plate counting is time-consuming and involves long incubation of samples - typically $72 \mathrm{~h}$. In consequence, the obtained results provide information on the historical condition of a given site. From safety management point of view, it means that the corrective or preventive actions taken are based on the data that is often inadequate to actual status of hygiene risks. Moreover, it is not possible to assess the effectiveness of safety related treatment, such as disinfection, in a real time.

The methods that enable rapid identification of microbiological and hygiene risks have been dynamically evolving and improving over the last decade. Adenosine-5'-triphosphate

\footnotetext{
${ }^{1}$ Institute of Environmental Engineering, Polish Academy of Sciences, ul. M. Skłodowskiej-Curie 34, 41-819 Zabrze, Poland, phone +48 3227164 81, fax +48 3227174 70, email: ipis@ipis.zabrze.pl

${ }^{2}$ SGS Polska sp. z o.o., ul. Cieszyńska 52a, 43-200 Pszczyna, Poland, phone +48 324492500 , fax +48 3244720 72, email: pl.envi@sgs.pl

*Corresponding author: alina.pohl@ipis.zabrze.pl
} 
(ATP) bioluminescence-based assay is more and more commonly used in practise. ATP is an organic molecule playing a role of energy carrier - all living cells (both prokaryotic and eukaryotic) contain this multifunctional coenzyme [1-3].

The technique of ATP determination was presented by Chappelle and Levin in 1968 [4]. It is highly precise and offers quick results that make the basis for decision-making and risk management. ATP tests may be used to measure cleanliness of technological lines and devices employed in food production. They can also be applied to assess hygiene of public utility facilities (hospitals), flats or hotels. Furthermore, they are useful for determining bacterial pollution of medicines, cosmetics, paints, drinking water, process water or air conditioning [4-6]. Moreover, the technique is applicable in wastewater treatment technology for determining wastewater quality and toxic effects of its pollutants and quick assessment of microorganisms' condition in biological wastewater treatment plants [7, 8].

Using ATP tests for determining microbiological pollution of water has a number of applications described in the literature. However, several references, for example Odom and Rotert [9], indicate that ATP tests can be useful for the measurement of biomass in water and wastewater. The reason why the assessments of ATP tests for water research are equivocal can originate from the fact that the first-generation tests had qualitative character, only. They also faced considerable uncertainty as there was no control of the activity of enzymes producing bioluminescence. LuminUltra's 2nd Generation tests used presently help to determine ATP related to active microorganisms with the application of the ATP standard for the calibration. They are qualitative and give repeatable results.

\section{Principle of ATP determination}

Determining ATP in samples with different matrices is carried out with bioluminescence. The measurement is based on the oxidative decarboxylation reaction of luciferin catalysed by the luciferase enzyme in the presence of ATP and magnesium ions [10]. The bioluminescence reaction occurs in the following way:

$$
A T P+O_{2}+\text { luciferin } \stackrel{\text { luciferase, } \mathrm{Mg}^{2+}}{\longrightarrow} \text { oxyluciferin }+A M P+\text { products }+ \text { light }
$$

In this process, the luciferase enzyme catalyses the transformation of luciferin to oxyluciferin where transition to the basic state due to the emission of light with an intensity proportional to the amount of ATP in the sample [2, 11, 12]. The intensity of light impulses that are formed in the luminescence reaction is measured at $562 \mathrm{~nm}$ and is expressed in Relative Light Units (RLU). The reaction should occur under proper pH (optimum 7.8-7.9) and temperature (optimum $25^{\circ} \mathrm{C}$ ) conditions $[13,14]$. The total ATP (tATP) in the sample is the sum of the cellular ATP (cATP), which occurs in the living cells, and the dissolved ATP (dATP), which comes from decomposed cells [15].

The analyses of cATP contents in water and wastewater samples show that its concentration in both aerobic and anaerobic bacteria cells is at the level of 1-2 $\mu \mathrm{g}$ ATP/mg cell [16]. On the other hand, Kowal and Libudzisz [3] claim that the bacterial cell contains on average approx. 1 femtogram of ATP $\left(1 \mathrm{fg}\right.$, ie $10^{-15} \mathrm{~g}$ of ATP). The concentration can range between 0.1 and $5.5 \mathrm{fg} / \mathrm{cell}$, depending on the species, physiology condition or metabolic activity of microorganisms. Luo et al [17] state that the average ATP concentration in a cell is approx. $0.47 \mathrm{fg} / \mathrm{cell}$. To estimate the number of microbes in a given sample, it is assumed that $1 \mathrm{pg}$ of ATP is equivalent to 1,000 bacteria cells (Table 1) $[3,18]$. 
ATP content in bacterial, mould and yeast cells [3]

\begin{tabular}{|c|c|}
\hline Microorganisms & ATP [fg/cell] \\
\hline Pseudomonas fluorescens & 0.6 \\
\hline Leuconostoc mesenteroides & 0.7 \\
\hline Escherichia coli & 1.0 \\
\hline Lactobacillus sp. & $2.0-2.2$ \\
\hline Bacteria mixture & 1.0 \\
\hline Kloeckera apiculate & 48.5 \\
\hline Pichia membranaefaciens & 90.7 \\
\hline Torulopsis sp. & 144.0 \\
\hline Saccharomyces cerevisiae & 155.0 \\
\hline Yeast mixture & 100.0 \\
\hline
\end{tabular}

\section{Using ATP tests in practice}

\section{Bioluminescence-based ATP assay as a universal hygiene monitor}

The epidemiological data on food poisoning indicate households as one of the places in which microbiological risks arise. The cross-contamination of surfaces and products is the probable reason for such a situation, particularly when raw meat is prepared. Pathogenic bacteria, such as Salmonella or Campylobacter, grow and spread easily under such conditions. The time of bacterial viability on many kitchen surfaces is between 4 and 24 hours. Appropriate hygienic procedures during food preparation, proper washing and disinfection are the most popular practices used to prevent microbial risks. Similar problems are observed in restaurants and public utility facilities (eg hotels). The ATP test helps to check easily whether a given surface is clean, sufficiently disinfected and does not constitute a threat for humans [14, 19, 20].

The ATP assay, as a diagnostic system of surface cleanliness [21], can be also used in the hygiene control of hospitals, public utility facilities, crèches, kindergartens or schools. It can be also applied in facilities for relaxation and recreation, such as swimming pools and water parks. It must be remembered that the referential values should be properly selected for the chosen utility surface and its usage [11, 22-24]. Griffith et al [25] established a procedure for analysing the microbiological pollution of surfaces (Fig. 1). 


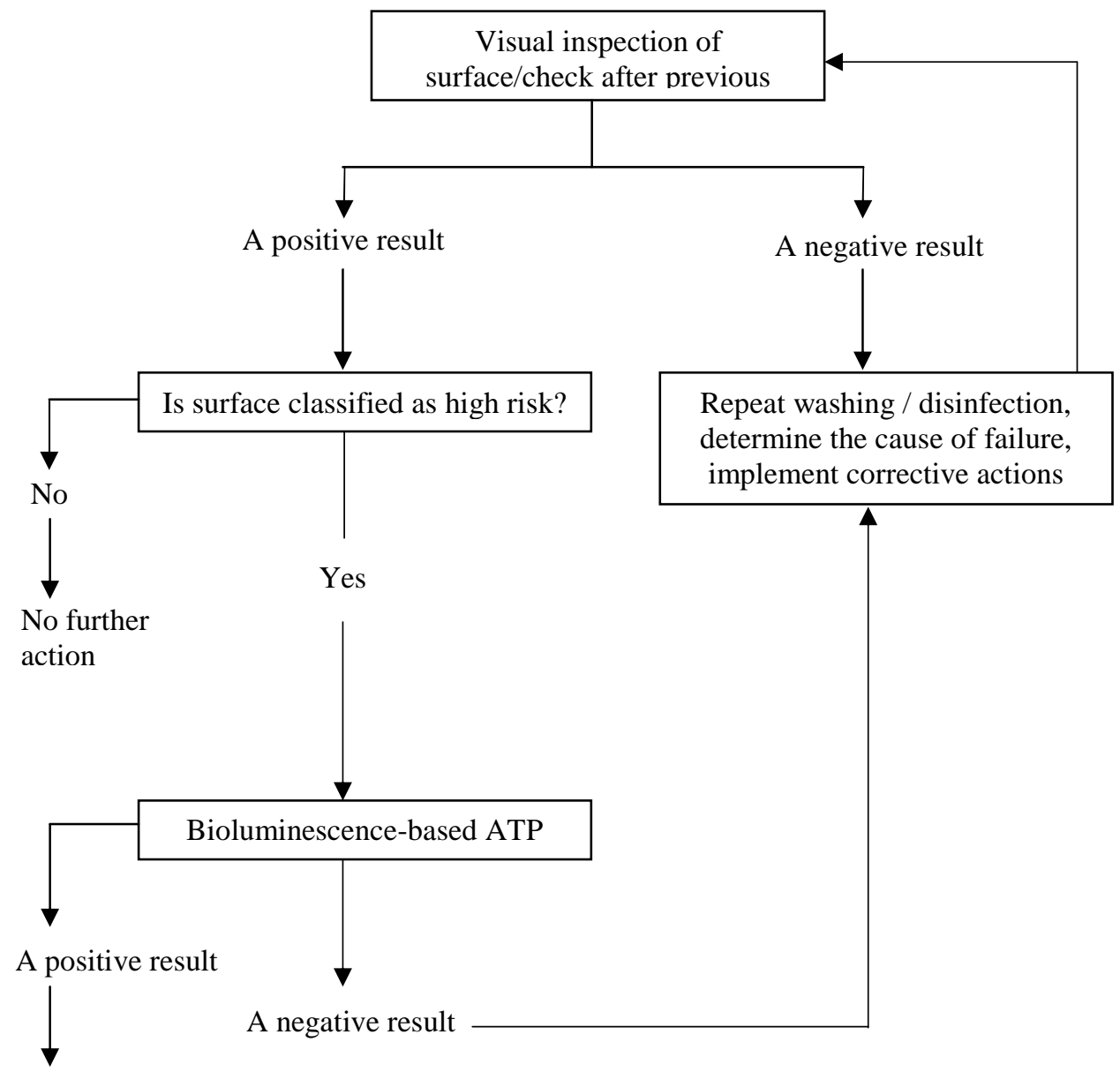

No further action

Fig. 1. Stages in the integrated cleaning programme [25]

\section{Hygiene monitoring in food industry}

Food industry is subject to the strict requirements for quality assurance systems and microbiological safety. To meet them, the following procedures are used: Good Hygienic Practice (GHP), Good Manufacturing Practice (GMP) and Hazard Analysis and Critical Control Points (HACCP) [26]. The HACCP system provides food safety by identifying and assessing hazards in terms of health requirements for food and the possibility of the risk during all production and distribution stages. The identification of the Critical Control Points (CPP) is one of the system principles. These are places in which special safety measures must be adopted and the hazards must be continuously monitored [27].

The regulations on hygiene impose on food producers the obligation of control which does not only concern raw materials, food additives and the final product but also the entire production cycle. The hygiene control of the production conditions should embrace: 
production environment (equipment used for heat treating and pasteurization, refrigerators and the remaining machines of technological lines); water used for food production; air in production halls; and the staff in direct contact with the product at different production stages [26, 28-30].

The total number of microbes is usually determined with colony plate counts methods, dilution methods, contact plate and swab methods or membrane filter techniques. They provide repeatable results that reflect the microbiological pollution. Unfortunately, the long time of the sample incubation (up to $72 \mathrm{~h}$ for bacteria; up to 5 days for fungi) does not enable quick corrections within one technological cycle [31, 32]. For that reason, it is necessary to introduce tests that quickly estimate the number of bacteria.

Sharpe recommended using the bioluminescence-based ATP assay in the food industry in 1970 [17, 29]. The method is becoming more and more popular in the hygiene monitoring in the HACCP system in situ. Its main advantage is detecting the microbial and organic pollutant within several minutes $[31,32]$.

In the food industry raw materials of plant or animal origin can raise ATP, thus the test results will be overstating. From the standpoint of cleanliness and hygiene it is not important that in the surface of the work and the production equipment are microorganisms or residues of biological material, eg blood, juice, etc. No bacteria does not guarantee the purity. Often organic debris are an excellent nutrient for microorganisms and can lead to contamination of the production line. In this case, the values are usually calculated based on the relative light units and not on obtained concentration of ATP. The results are compared with the threshold values, previously designated for the industry and the individual measuring points. Low levels of RLU indicates that the measuring point is clean and free from organic and microbiological pollutants, when the RLU level is high, point should be considered as contaminated. When the value of RLU is to high it must be taken corrective action, for example extending the cleaning and disinfection, increasing the concentration of the cleaning and disinfecting agent or changing the applied formulation [33].

The ATP assays are most often used for the hygiene monitoring of production in the dairy [1] and meat industries [34] and in the production of carbonated soft drinks, fruit juice and beer. They are also applied for the control of cleanliness in food transport vehicles ( $\mathrm{eg}$ road tankers), glass and plastic containers [26].

\section{Microbiological analyses of drinking water}

The World Health Organization (WHO) guidelines for the preparation and introduction of Water Safety Plans (WSP) were developed in 2004. The plans are based on the risk assessment and management and the HACCP principles. Their aim is to minimalize the health risk in water supply at all stages. It is done by systematic identification of risks, ordering them according to their importance and operational monitoring of all water production and distribution stages [35].

WSPs are designed to replace the traditional approach to water quality monitoring with the process-based approach that relies on risk analyses used within daily management procedures. Their main assumption is the complex approach to supplying people with water. It should take into consideration all parties involved in the water supply: water owners or administrators, water suppliers, land and property users. Water suppliers should play a central role in this process [35].

The policy requires proper tools. Determining standardized indicators of microbiological water pollution is time-consuming due to the long incubation of samples. 
The results obtained in this way are hardly useful for the on-going operational actions and dealing with crisis situations. The research conducted since 1990s shows that analyses of cATP in water can provide the necessary tool. The determinations can be used at all treatment and monitoring stages - from the well to the outlet of a distribution network. It can also be employed to optimize the process of water treatment and to analyse the condition of water supply systems. It is also possible to determine all forms of microorganisms in water during the analysis $[8,15,36]$.

The total number of bacteria incubated on agar is determined in the microbiological analyses. It only concerns heterotrophic bacteria. On the other hand, autotrophic bacteria (nitrifying, iron, sulphur and manganese bacteria) and viable but nonculturable (VBNC) bacteria can also occur in tap water $[37,38]$. VBNC bacteria are not able to grow on growth media like agar but they remain in the physiologically active form. The passing of cells into the VBNC state usually occurs under the influence of stressors. The passing of pathogenic bacteria cells (eg Salmonella sp, Campylobacter jejuni, Vibrio vulnificus, Vibrio parahaemolyticus, Yersinia enterocolitica and Escherichia coli) into VBNC forms is particularly dangerous, as they remain active all the time. Additionally, they have higher virulence than the cells which are not influenced by the stressors [39, 40].

The applied water disinfection and treatment processes eliminate mainly vegetative bacterial forms whereas bacterial endospores may remain intact. Water disinfection creates stressing conditions in bacteria and induces the VBNC state. The process also takes place in cells that make the biofilm, which negatively affects water quality and can also counteract the effects of disinfectants [41]. Importantly, cells in the VBNC state can occur in the biofilm that does not undergo disinfection processes. Notably, the older the biofilm, the higher number of the VBNC cells in it. Consequently, classic methods for detection and qualitative determination of strains forming the biofilm may be insufficient. The presence of microbes in the VBNC state in a given environment can be detected with methods of cell viability determination, such as the ATP assay, and without using traditional agar plating techniques [39].

Some research [42] indicates that the ATP test can be used to optimize the work of water treatment plants. It is particularly useful for smaller water intakes in which water treatment mainly consists in removing iron, manganese and suspended solids. The authors observed the correlation between the time of the filtration and backwashing cycles and the ATP content in the filtrate and washing water. The test enables the evaluation of the filter work and experimental determination of the cycle length. It may be important for the reduction of the organic content introduced into the system. Hence, the biofilm formation on the water pipe walls can be limited. As a result, it can bring savings as the number of filter bed flushings and the time these processes take are reduced. Moreover, extending the filtration cycle should improve water quality in the system $[8,42]$.

A significant number of studies concern water supply systems. Researchers often observe the correlation between the content of heterotrophic bacteria and the ATP concentration. Nonetheless, it is not mentioned in all reports. On one hand, this phenomenon can be caused by bacteria that do not occur in the vegetative form. On the other hand, it can be influenced by autotrophic bacteria (nitrifying, iron, sulphur and manganese ones) that make the filter bed biofilm. Recent studies demonstrate the use of the ATP assay to determine hazards related to the formation of biofilm on water pipe walls $[18,43-45]$. 
Analysing ATP contents in water at the intake point establishes the correlation between the time of the day and microbiological pollution [18]. In the analysed case, the highest ATP values were observed at about 8 a.m. They decreased significantly between 8 and 10 a.m. The concentration did not change until 6 p.m. This study shows a correlation between the biofilm formation and the resulting content of microorganisms in water. At night, when there was no intake, a secondary contamination of water occurred, resulting from the biofilm growth on the water pipe walls.

When it comes to health safety of water, ATP tests are presently employed to control facilities, such as hotels and holiday centres in tourist resorts, where the dynamics of water uptake varies greatly - from stagnation to a continuous flow. The determinations can be carried out directly on-site. As a result, it is easy to determine the necessary time required for the backwashing of internal networks, which enables rapid improvement in the hygienic conditions and reduction of human exposure to a health risk.

The research conducted in Poland in the years 2008-2012 focused on the possibility of using ATP analyses to determine microbiological pollution of intake and treated water, water in the supply system and water in the internal installations of public utility buildings. The findings were compared with the results of classical plate count methods $[8,36]$.

Significant differences in the processes of water intake and treatment were observed at underground and surface water intakes. The cATP content ranged between 0.6 and $14.5 \mathrm{pg} \mathrm{cATP} / \mathrm{cm}^{3}$ for underground water at exploited water intakes. Its value exceeded $20.9 \mathrm{pg} \mathrm{cATP} / \mathrm{cm}^{3}$ in the unexploited wells. This diversification shows the influence that the well close-down has on the microbiological pollution. The content usually rises during the removal of iron and manganese in the course of underground water treatment. At the same time no increase in heterotrophic bacteria is observed. However, autotrophic bacteria (nitrifying, iron, manganese or sulphur ones) inhabiting the filter bed can get into the filter leachate. In water supply systems these microorganisms can form the biofilm on the water pipe walls or act as a growth media for the forming biofilm. Consequently, water quality deteriorates. The obtained results also indicate risks related to the microbiological water pollution occurring at the plant in which units for water intake and treatment are inappropriately disinfected. The cATP value in water after filtration sometimes considerably exceeds the content observed in raw water [8].

The changes in the cATP content during surface water treatment were different. Its total content in the intake water was $66.5 \mathrm{pg} \mathrm{cATP} / \mathrm{cm}^{3}$. A complex treatment process, containing sedimentation, intermediate ozonation, conventional coagulation and activated carbon water filtration, was used. After the treatment was completed, the indicator value dropped to $5.6 \mathrm{pg} \mathrm{cATP} / \mathrm{cm}^{3}$. It was disinfection with chlorine and proper contact time that reduced the value to $0.6 \mathrm{pg} \mathrm{cATP} / \mathrm{cm}^{3}$ [8].

Interesting results were obtained during determinations of cATP in the water supply system. The analysis of the results presented so far indicates that the farther it is from the water treatment plant, the more cATP content rises. It is particularly notable for significantly long systems that supply low water amounts. The obtained cATP values help to determine "black spots", ie places in which microbiological pollution should be expected. It is the effect of the biofilm growing in the supply system. The water pipe age and material contribute to the biofilm growth. Certain materials used for water pipe production can contribute to the release of chemical compounds (eg copper, iron, phosphorus) that intensify the biofilm growth [36, 46-49]. 


\section{Usable hot water}

The occurrence of Legionella pneumophila in usable hot water is one of the major risks related to internal water networks. The bacteria proliferate at $20-45^{\circ} \mathrm{C}$ and occur mainly in the aqua-air aerosol. People who work or stay in places such as hydrotherapy spas, swimming pools or car washes can easily contract an illness. The reports show that approximately $20 \%$ of cases occur in individual households equipped with tank water heaters (boilers). Legionella pneumophila are contained in the biofilm that grows in pipes, tanks, etc. Consequently, hot water installations in public utility facilities (hospitals, residential care homes, etc) are highly exposed to their occurrence. The mandatory regulation of the Polish Ministry of Health imposes the obligation of Legionella water testing on such facilities. The provisions in force state that the Legionella content in water should be lower than $100 \mathrm{CFU} / 100 \mathrm{~cm}^{3}$. The determination of Legionella sp. in hot water is also related to the long incubation time. It seems that ATP is a useful indicator for routine control $[50,51]$.

The tests conducted so far seem to prove the method utility. For the majority of compared tests, the cATP content in heated water was much higher than that in cold water from the same water intake point. The ATP content in the centrally supplied hot water was between 2.17 and $3.28 \mathrm{pg} \mathrm{cATP} / \mathrm{cm}^{3}$ in the hot water installation commissioned shortly before the tests. The ATP content in cold water samples from the same intake point was $0.37-0.39 \mathrm{pg} \mathrm{cATP} / \mathrm{cm}^{3}$. The high values, which considerably exceeded $100 \mathrm{pg} \mathrm{cATP} / \mathrm{cm}^{3}$, were also observed in hot water in the examined Polish hospital buildings. The cATP assay seems particularly useful for facilities in which devices are periodically supplied with hot water, such as hotels or holiday centres [8].

\section{Using ATP assays to assess waste water treatment plant performance}

ATP tests can be supplementary to standard analyses of wastewater treatment. On one hand, they enable rapid assessments of treatment process effectiveness, activated sludge condition and treated wastewater quality. On the other hand, they allow evaluating the toxicity of pollutants brought into a wastewater treatment plant. They can also be useful in the period of the activated sludge adaptation to the changing substrate $[7,52,53]$.

The evaluation of the toxic effects of the wastewater supplied to the treatment plant can be made in both technical and laboratory scale. It is assumed that only part of ATP can occur in the form of dissolved, extracellular ATP (dATP) in this kind of wastewater. The ratio of the dissolved ATP (dATP) to the total ATP (tATP) is known as the Biomass Stress Index (BSI) given by:

$$
\operatorname{BSI}(\%)=\frac{d A T P}{t A T P} \cdot 100 \%
$$

According to the test authors, the BSI value below 50\% is typical for good-quality wastewater that should not contain toxic substances. The BSI of $75 \%$ is a situation that requires corrective actions [15].

Two indicators based on the ATP analysis are recommended for the assessments of the state and condition of biomass in a bioreactor. The first is the BSI, in which action thresholds are changed to 30 and $50 \%$, respectively. The other one is the number of bacteria remaining in the Active Biomass Ratio $(A B R)$, given by 


$$
A B R(\%)=\frac{A V S S}{T S S} \cdot 100 \%
$$

where: AVSS - Active Volatile Suspended Solids; represents the total mass of living organisms contained in the sample; the content of cATP in the suspended solids, calculated according to the formula: $A V S S=\mathrm{cATP} \cdot 0.5 \mathrm{mg} / \mathrm{cm}^{3}$. Where 0.5 is a conversion factor from ATP concentration to dry biomass concentration (a biomass population contains 250 parts of biomass carbon per 1 part of intracellular ATP and that biomass is approximately $50 \%$ carbon on a dry basis), TSS - Total Suspended Solids [mg/dm $\mathrm{dm}^{3}$.

For a well-working reactor, the ABR is higher than $25 \%$. The value below $10 \%$ constitutes a threshold for which corrective actions are necessary. The higher the ABR is, the better sludge settling characteristics are. The best working conditions of the reactor are achieved when the BSI is as low as possible whereas the ABR is as high as possible at the same time [15].

The research into the substrate toxicity and the adaptation of the activated sludge to the changing substrate is conducted in the laboratory or semi-technical scale. The assessment concerns analysing the correlations between cATP and dATP and between these two forms and tATP. A sudden increase in dATP coupled with simultaneous decrease of cATP indicates that there are agents in the substrate that adversely affect the treatment process. The coefficients given by the above-mentioned interdependences can be also used for the evaluation. In such a case, the ATP test can replace other, more time-consuming analyses.

The content of free bacteria in treated wastewater found at the outlet of the secondary precipitation tank is one of the indicators for the proper bioreactor operating. The value ought to be as low as possible $[54,55]$. The microscopic examinations of such bacteria can be replaced with the cATP analysis. Such an action seems to be easier to perform, while the results are more comparable than those obtained with microscopic methods.

\section{Environmental research}

Some studies indicate that it is possible to apply ATP tests to the analyses of water quality in rivers, streams and stagnant water reservoirs. Nonetheless, there have been no reports that describe such applications so far. The possibility for determining both cATP and dATP seems to predispose the test to the research into phases of phytoplankton and zooplankton growth in stagnant water [56].

\section{Summary and conclusions}

The necessity for rapid identification of hygiene risks requires the introduction and improvement in testing for determinations of microbial and organic contamination. Among rapid biochemical methods, the ATP test is becoming more and more important. It can be used as a tool for industrial applications including food industry, monitoring of environmental risk, hygiene monitoring, process and drinking water control, biomass content control in water distribution networks, wells and treatment stations, reservoirs and air-conditioning systems. It can also be applied to verify the cleanliness of products such as cosmetics, pharmaceutical substrates, paints etc. It can be also employed to determine the condition of the activated sludge and the toxic effect caused by chemical agents present in active sludge $[4-6,8,19]$.

The advantages of the ATP test include: short time of the sample analysis (a few minutes) in comparison with traditional methods; the possibility of doing the test in situ; 
test performance simplicity; usefulness for present operational actions; immediate assessment of the risk and taking proper remedial actions [7, 19, 57]. On the other hand, the ATP assay is not a specific test. It does not provide precise information on particular pollutants. In a water sample the ATP test allow for indicating all microorganisms in the sample - heterotrophic and autotrophic bacteria, yeast, molds, algae, protozoa. Whereas in a food industry the ATP assay provides information about the organic and microbial contamination. [6, 19, 58].

The review of the available data indicates that ATP assays can be supplementary to classic microbiological research methods. They are particularly useful for present operational actions. The possibility of obtaining results in the field conditions is the basis for decision-making and risk management in the place where the risk appears.

\section{References}

[1] Griffiths MWJ. Dairy Sci. 1993;76:3118-3125. DOI: 10.3168/jds.S0022-0302(93)77651-1.

[2] Marques SM, Esteves da Silva JCG. IUBMB Life. 2009;61(1):6-17. DOI: 10.1002/iub.134

[3] Kowal K., Libudzisz Z. Mikrobiologia techniczna. Łódź: Wydawnictwo Politechniki Łódzkiej; 2000.

[4] Yoon KY, Park CW, Byeon JH, Hwang J. Environ Sci Technol. 2010;44(5):1742-1746. DOI: 10.1021/es903437z.

[5] Farris L, Habteselassie MY, Perry L, Chen SY, Turco R, Reuhs B, et al. Luminescence Techniques for the Detection of Bacterial Pathogens. In: Zourob M, Elwary S, Turner A, editors. Principles of Bacterial Detection: Biosensors, Recognition Receptors and Microsystems. New York: Springer Publishing; 2008. http://link.springer.com/chapter/10.1007\%2F978-0-387-75113-9_10\#page-1.

[6] Hammes F, Goldschmidt F, Vital M, Wang Y, Egl T. Water Res. 2010;43(13):3915-3923. DOI: 10.1016/j.watres.2010.04.015.

[7] Dalzell D, Christofi N. Water Res. 2002;36(6):1493-1502. DOI: 10.1016/S0043-1354(01)00346-3.

[8] Samendra PS, Masaaki K, Charles PG, Ian LP. Water Biosens J. 2014;3(1):2-8. DOI: 10.4172/2090-4967.1000109.

[9] U.S. Environmental Protection Agency (EPA). Distribution System Indicators of Drinking Water Quality. Washington: DC; 2006. http://pubweb.epa.gov/safewater/disinfection/tcr/pdfs/ issuepaper_tcr_indicators.pdf.

[10] Ochromowicz K, Hoekstra EJ. ATP as an indicator of microbiological activity in tap water. European Commision Directorate - General Joint Research Centre; 2005. http://publications.jrc.ec.europa.eu/ repository/bitstream/JRC32609/2609\%20-\%20EUR22157\%20ATP.pdf.

[11] Aiken ZA, Wilson M, Pratten J. Infect Control Hosp Epidemiol. 2011;32(5):507-509. DOI: 10.1086/659761.

[12] Steinberg SM, Poziomek EJ, Engelmann WH, Rogers KR. Chemosphere. 1995;30(11):2155-2197. DOI: 10.1016/0045-6535(95)00087-9.

[13] Calvert RM, Hopkins HC, Reilly MJ, Forsythe SJ. Letters in Applied Microbiol. 2000;30(3):223-227. DOI: 10.1046/j.1472-765x.2000.00703.x.

[14] Griffith CJ, Peters AC, Fielding LM. Luminescence. 1999;14(1):33-38. DOI: 10.1002/(SICI)1522-7243(199901/02)14:1<33::AID-BIO514>3.0.CO;2-I.

[15] LuminUltra Technologies Ltd. Test Kit Instructions. Test Kit Product: QuenchGone21TM Wastewater Test Kit Product: QG21W-50/QG21Wb-25, QGA-25/QGA-100, Canada. http://www.luminultra.com/ wp-content/uploads/2013/06/qg21w.pdf.

[16] Droste RL. Theory and Practice of Water and Wastewater Treatment. New York: John Wiley \& Sons; 1997.

[17] Luo J, Liu X, Tian Q, Yue W, Zeng J, Chen G, et al. Anal Biochem. 2009;394(1):1-6. DOI: 10.1016/j.ab.2009.05.021.

[18] Siebel E, Wang Y, Egli T, Hammes F. Drink Water Eng Sci. 2008;1:71-86. DOI: 10.5194/dwes-1-1-2008.

[19] Hawronskyj J, Holah J. Trends Food Sci Technol. 1997;8(8):79-84. DOI: 10.1016/S0924-2244(97)01009-1.

[20] Larson E, Aiello A, Gomez-Duarte C, Lin S, Lee L, Della-Latta P, et al. Food Microbiol. 2003;20(6):735-739. DOI: 10.1016/S0740-0020(03)00041-8.

[21] Jasson V, Jacxsens L, Luning P, Rajkovic A, Uyttendaele M. Food Microbiol. 2010;27:710-730. DOI: 10.1016/j.fm.2010.04.008.

[22] Cooper R, Griffith C, Malik R, Obee P, Looke N. Am J Infect Control. 2007;35(5):338-341. DOI: 10.1016/j.ajic.2006.07.015 
[23] Sherlock O, O'Connell N, Creamer E, Humphreys H. J Hosp Infect. 2009;72(2):140-146. DOI: 10.1016/j.jhin.2009.02.013.

[24] Venkateswaran K, Hattori N, Duc M, Kern R. J Microbiol Methods. 2003;52(3):367-377. DOI: 10.1016/S0167-7012(02)00192-6.

[25] Griffith CJ, Cooper RA, Gilmore J, Davies C, Lewis M. J Hosp Infect. 2000;45:19-28. DOI: 10.1053/jhin.1999.0717.

[26] Junchao L, Xiao-Hui P, Chi-Te L, Che-Lang C, Kuan-Chen C. J Food Drug Analysis. 2014;22(3):391-398. DOI: 10.1016/j.jfda.2013.09.049

[27] Mayes T. Food Control. 1992;3(1):14-19. DOI: 10.1016/0956-7135(92)90167-9.

[28] Bautista DA, Sprung DW, Barbut S, Griffiths MW. Food Res Int. 1997;30(10):803-809. DOI: 10.1016/S0963-9969(98)00049-0.

[29] Sharpe AN, Woodrow MN, Jackson AK. J Applied Bacteriol. 1970;33(4):758-767, DOI: 10.1111/j.1365-2672.1970.tb02260.x.

[30] Lelieveld HLM, Holah J, Napper D. Hygiene in Food Processing (Second Edition). Philadelphia: Woodhead Publishing Limited; 2014.

[31] Davidson CA, Griffith CJ, Peters AC, Fielding LM. Luminescence. 1999;14(1):33-8. DOI: 10.1002/(SICI)1522-7243(199901/02)14:1<33::AID-BIO514>3.0.CO;2-I.

[32] Otero A, Garcia-Lopez M-L, Moreno $\quad$ B. Meat Sci. 1998;49(1):179-189. DOI: 10.1016/S0309-1740(98)00083-7.

[33] Aycicek H, Oguz U, Karci K. Int J Hyg Environ Health. 2006;209:203-206. DOI: 10.1016/j.ijheh.2005.09.007.

[34] Siragusa GR, Cutter CN, Dorsa WJ, Koohmaraie M. J Food Prot. 1995;58:770-775.

[35] Viljoen FC. Water Sci Technol. 2010;61(1):173-9. DOI: 10.2166/wst.2010.792

[36] Zhu Z, Wu C, Zhong D, Yuan Y, Shan L, Zhang J. Appl Biochem Biotechnol. 2014;173(6):1564-78. DOI: 10.1007/s12010-014-0935-x.

[37] Decamp O, Warren A. Water Res. 2001;35(14):3496-3501. DOI: 10.1016/S0043-1354(01)00064-1.

[38] Young JL, Deininger RA. Am Lab. 2001;33(21):24-26.

[39] Dinu LD, Delaquis P, Bach S. Nonculturable response of animal enteropathogens in the agricultural environment and implications for food safety. $\mathrm{J}$ Food Prot. 2009;72(6):1342-54. https://www.researchgate.net/publication/26678083_Nonculturable_response_of_animal_enteropathogens_i n_the_agricultural_environment_and_implications_for_food_safety.

[40] Oliver JD. J Microbiol. 2005;43:93-100.

[41] Delahaye E, Welte B, Levi Y, Leblon G, Montiel A. Water Res. 2003;37(15):3689-3696. DOI: 10.1016/S0043-1354(03)00288-4.

[42] Costa PD, de Andrade NJ, Vieira Passos FJ, Sebastião Brandão SC, Rodrigues CG. Braz Arch Biol Technol. 2004;47(3):399-405. DOI: 10.1590/S1516-89132004000300010.

[43] Deininger R, Lee J. Field Anal Chem Technol. 2001;5(4):185-189. DOI: 10.1002/fact.1020.

[44] Deininger R, Lee J. Rapid detection of bacteria in drinking water. In: Omelchenko A, Pivovarov AA, Swindall WJ, editors. Modern Tools and Methods of Water Treatment for Improving Living Standards. Netherlands: Springer; 2005. http://link.springer.com/chapter/10.1007\%2F1-4020-3116-5_4\#page-1.

[45] Deininger R, Lee J, Clark R. Front Earth Sci. 2011;5(4):378-389. DOI: 10.1007/s11707-011-0206-X.

[46] Yu J, Kim D, Lee T. Water Sci Technol. 2010;61(1):163-71. DOI: 10.2166/wst.2010.813.

[47] Lehtola M, Laxander M, Miettinena I, Hirvonenc A, Vartiainen T, Martikainen P. Water Res. 2006;40(11):2151-2160. DOI: 10.1016/j.watres.2006.04.010.

[48] Rożej A, Cydzik-Kwiatkowska A, Kowalska B, Kowalski D. World J Microbiol Biotechnol. 2015;31:37-47. DOI: $10.1007 / \mathrm{s} 11274-014-1761-6$.

[49] Yu J, Kim D, Lee T. Water Sci Technol. 2010;61(1):163-171. DOI: 10.2166/wst.2010.813.

[50] Kooij D, Veenendaal H, Scheffer W. Water Res. 2005;39(13):2789-2798. DOI: 10.1016/j.watres.2005.04.075.

[51] Douterelo I, Boxall JB, Deines P, Sekar R, Fish KE, Biggs CA. Water Res. 2014;(65):134-156. DOI: 10.1016/j.watres.2014.07.008.

[52] Hwang S, Hansen C. Bioresour Technol. 1998;63(3):243-250. DOI: 10.1016/S0960-8524(97)00131-4.

[53] Tam N. Environ Pollut. 1998;102:33-242. DOI: 10.1016/S0269-7491(98)00084-0.

[54] Naidoo S, Olaniran AO. Int J Environ Res Public Health. 2014;11(1):249-270. DOI: 10.3390/ijerph110100249.

[55] Cheng HW, Lucy FE, Broaders MA, Mastitsky SE, Chen CH, Murray AJ. Water Health. 2012;10(3):380-9. DOI: 10.2166/wh.2012.138. 
[56] Eaton A, Clesceri L, Rice E, Greenberg A. Standard methods for the examination of water and wastewater. Washington: American Public Health Association, American Water Works Association, Water Environment Federation; 2005.

[57] Kooij D. Managing regrowth in drinking water distribution systems. In: Cotruvo J, Exner M, Fricker C, Glasmacher A, editors. Heterotrophic Plate Counts and Drinking-water Safety. London, UK: WHO, IWA Publishing; 2003. http://www.who.int/water_sanitation_health/dwq/HPC11.pdf.

[58] Carrascosa C, Saavedra P, Millán R, Jaber JR, Pérez E, Grau R, et al. Food Control. 2012;28:368-373. DOI: 10.1016/j.foodcont.2012.05.001. 